\title{
https://doi.org/10.46813/2021-131-019 \\ DESIGN AND APPLICATION OF GLOW DISCHARGE CLEANING AT URAGAN-2M STELLARATOR
}

\author{
Yu.V. Kovtun, V.E. Moiseenko, S.M. Maznichenko, A.V. Lozin, V.B. Korovin, E.D. Kramskoy, \\ Y.V. Siusko, M.M. Kozulya, A.Yu. Krasiuk, V.M. Listopad, D.I. Baron
Institute of Plasma Physics, National Science Center "Kharkov Institute of Physics and Technology", Kharkiv, Ukraine

\section{E-mail: Ykovtun@kipt.kharkov.ua}

For the Uragan-2M stellarator, a glow discharge cleaning (GDC) system is developed. An overview of the GDC system design is presented. The first experimental studies of GDC in an argon atmosphere have been carried out. The dependence of the breakdown voltage on the argon pressure is determined. The current-voltage characteristics of the gas discharge were measured as a function of the working gas pressure also in presence of a magnetic field.

PACS: 52.80.-s; 52.80.Hc; 51.50.+v

\section{INTRODUCTION}

In experimental studies of high-temperature plasma, which are aimed at solving the problems of controlled thermonuclear fusion, it is important to reduce the flux of light and heavy impurities to the plasma column. Presence of impurities at the inner walls of the vacuum chambers of installations for high-temperature plasma confinement leads to their entry into the plasma and, accordingly, to several negative consequences as decrease of plasma parameters, increase of energy losses, and even to radiation collapses and disruptions in the case of tokamaks. For this reason, the preparation of inner vacuum surfaces is an integral part of the functioning of fusion installations.

Various methods are used for wall conditioning [1, 2]. To create plasma in cleaning modes, various types of cleaning discharges, both stationary and pulsed, are used. Glow discharge [1,2] and various types of highfrequency discharges [1-7] are widely used for cleaning the inner surfaces of vacuum chambers of tokamaks and stellarators. High-frequency discharges in various frequency ranges (electron-cyclotron frequency [1-3], ion-cyclotron frequency [1-3], ultrashort waves $[6,7]$ ) are used mainly in the presence of a magnetic field. on the contrary Glow discharge cleaning (GDC), is used mainly without a magnetic field, although, in principle, the discharge can also burn in a magnetic field. The advantage of a glow discharge is the possibility of implementing it in large vacuum volumes and technical simplicity. A significant disadvantage is the sputtering of materials in contact with the plasma, which leads to the deposition of metal films on the equipment located in it $[8,9]$. Despite this drawback, the technology of cleaning the wall of the vacuum chamber with a glow discharge plasma is the most common and is used in large installations, for example, in TEXTOR [8], Wendelstein 7-X [9-11], ASDEX-U [12], JET [13], LHD [14], EAST [15], SST-1 [16]. In the future, it is planned to use the GDC system at ITER [17].

Each of the systems used for GDC has its own design and technical features. Common to all systems is the use of a vacuum chamber wall as a cathode, and specially designed electrodes as anodes, which are placed into the vacuum volume. The number of ISSN 1562-6016. BAHT. 2021. №1(131)

PROBLEMS OF ATOMIC SCIENCE AND TECHNOLOGY. 2021, №1. Series: Plasma Physics (27), p. 19-24. electrodes (anodes) is usually from 2 (SST-1 [16], LHD [14]) to 4 (ASDEX-U [12], JET [13], EAST [15]). The electrodes (anodes) 10, are installed on Wendelstein 7-X [9-11]. The electrodes are usually placed symmetrically along the torus. Stainless steel $[15,16]$ or graphite [912] are used as the electrode material.

Earlier, the Uragan-2M (U-2M) stellarator did not use a glow discharge to clean the vacuum chamber, and, accordingly, the installation was not equipped with an electrode system for its implementation. The GDC system at the U-2M would allow expanding the experimental capabilities when conducting experiments on cleaning the vacuum chamber. Therefore, the GDC system was developed, manufactured, and installed on the U-2M. The design and technical features of which, as well as the results of the first studies of a glow discharge, are presented in this work.

\section{EXPERIMENTAL SETUP}

The U-2M setup (see Fig. 1) is a medium-sized stellarator (torsatron type) with a major radius $R=1.7 \mathrm{~m}$, the average plasma radius $r_{\mathrm{pl}}<0.24 \mathrm{~m}$, and a toroidal magnetic field $B_{0}<2.4 \mathrm{~T}$ [18]. The vacuum chamber has a toroidal shape with a radius of $r_{\mathrm{c}}=0.34 \mathrm{~m}$, a volume of $V_{\mathrm{c}}=3.9 \mathrm{~m}^{3}$ (excluding vacuum ports), and a torus surface area $S=22.8 \mathrm{~m}^{2}$. The chamber has 48 ports, which are used for diagnostic tools, for working gas puff, and vacuum pumping. The vacuum chamber is pumped using three turbomolecular pumps of the TMN500 type with a pumping rate of $500 \mathrm{l} / \mathrm{s}$. In the forevacuum pressure area, pumping is carried out only by a mechanical fore-vacuum pump AVZ-63D with a pumping speed of $63 \mathrm{l} / \mathrm{s}$.

\section{OVERVIEW OF THE GDS DESIGN}

A system of 4 identical water-cooled electrodes (anodes) was developed, manufactured and installed on the U-2M. They were made in the form of bent cylindrical rods made of stainless steel (Fig. 2,a). The length of the current-collecting part of the electrode was $59 \mathrm{~cm}$, the diameter was $2 \mathrm{~cm}$. The electrodes are installed on a standard flange with a feedthrough insulator made of fluoroplastic F-4. The measured resistance between the electrode and the flange was 
more than $200 \mathrm{M} \Omega$. Use of water to cool the electrodes reduces the resistance between the electrode and the vacuum chamber to a value of $\sim 300 \mathrm{k} \Omega$. To prevent breakdown, a part of the electrode, $10.5 \mathrm{~cm}$ long, is covered with a quartz tube $\varnothing 38$ and $2 \mathrm{~mm}$ thick (see Fig. 2,a).

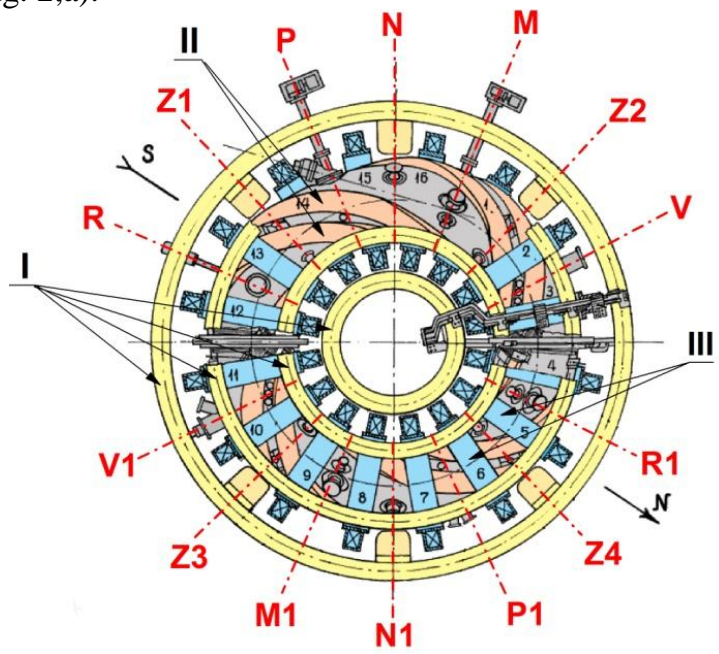

Fig. 1. Scheme U-2M. I-poloidal coils; II-helical coils; III - toroidal field coils toroidal field coils numbered 1-16

This design also increases the distance from the currentcollecting part of the electrode to the chamber wall. The area of the current-collecting surface of one electrode is $392 \mathrm{~cm}^{2}$. The total area of four electrodes is $1560 \mathrm{~cm}^{2}$. The electrodes were installed on the U-2M (Fig. 2,b) at standard ports $\varnothing 45 \mathrm{~mm}$ in the cross-sections $\mathrm{Z1}, \mathrm{Z2}, \mathrm{Z3}$, Z4 (see Fig. 1). The electrodes were located at a distance of $3 \mathrm{~cm}$ from the last closed flux surface at $k_{\varphi}=0.32\left(k_{\varphi}=B_{\mathrm{th}} /\left(B_{\mathrm{th}}+B_{\mathrm{tt}}\right)\right.$, where $B_{\mathrm{th}}$ and $B_{\mathrm{tt}}$, are the toroidal components of the magnetic fields created by the helical and toroidal coils respectively). They are directed along the plasma column to keep maximum distance from the chamber wall and, in the same time, not to penetrate into the plasma column.

A universal power supply of the UIP-1 type was used to feed the glow discharge, the output voltage on which could be smoothly tuned from 20 to $610 \mathrm{~V}$ at a current of up to $600 \mathrm{~mA}$. To feed the discharge at higher discharge currents and voltages, a power supply unit with an output voltage of up to $1.9 \mathrm{kV}$ at a current of up to $5 \mathrm{~A}$ was used. The electric scheme for the glow discharge is shown in Fig. 3. The voltage at the discharge gap was measured with voltmeters V1 and $\mathrm{V} 2$, and the total anode current was measured with an ammeter (milliammeter). To avoid arcing, two ballast resistors $\mathrm{R}$ were used, each with a resistance of $1026 \Omega$ (total resistance $513 \Omega$ ). Assuming the resistance between each electrode and the vacuum chamber $\sim 300 \mathrm{k} \Omega$, the maximum earth leakage current at $610 \mathrm{~V}$ is $\sim 8 \mathrm{~mA}$.

\section{EXPERIMENTAL RESULTS AND DISCUSSION}

The first experiments to study the GDC were carried out after two weeks of wall conditioning of the U-2M chamber. During the first week of 4 days, the chamber was baked at temperature of $70 \ldots 80{ }^{\circ} \mathrm{C}$ and pumped. In the second week, the surfaces of the chamber were cleaned with $\mathrm{N}_{2}$ and Ar plasma created by a stationary discharge in the very high frequency (VHF) range with baking continued.
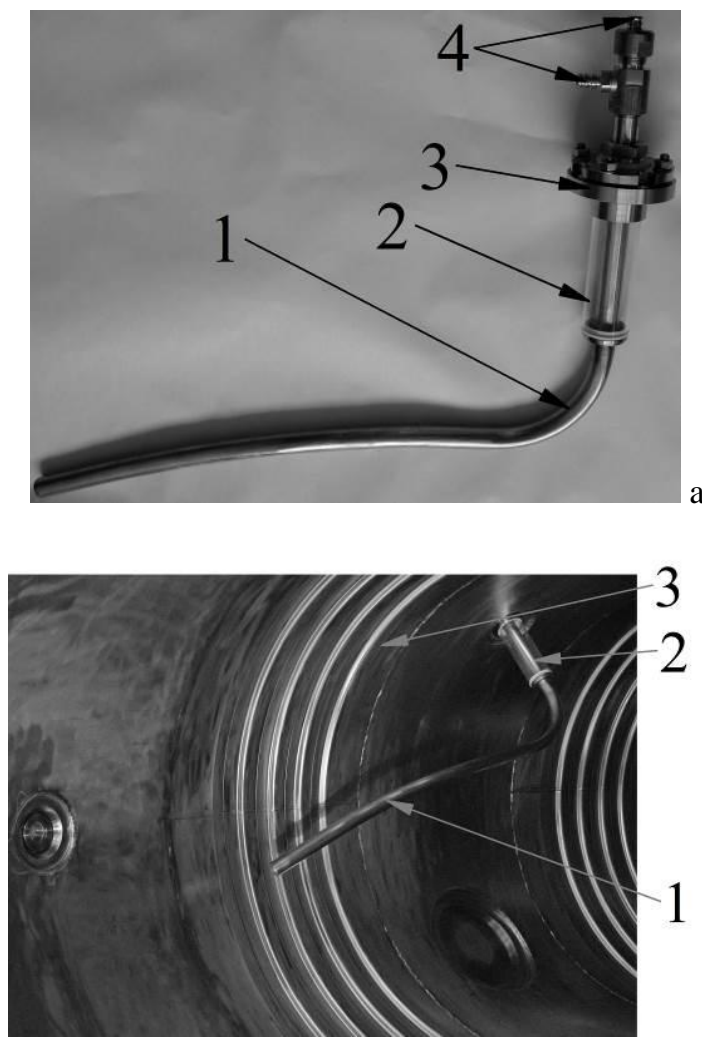

b

Fig. 2. Photo of a general view of the electrode (anode). $a$-assembled before installation in $U-2 M$

(1-electrode, 2 -insulator, 3 -flange, 4-water inlet and outlet pipes); $b$ - in the $U-2 M$ vacuum chamber

(1-electrode, 2 -insulator, 3 - the wall of the vacuum chamber)

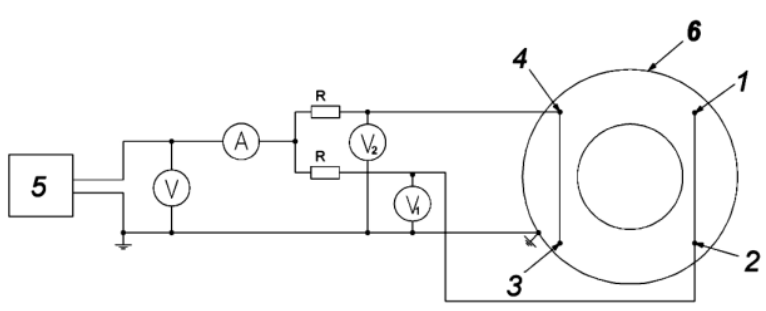

Fig. 3. Scheme of connecting electrodes to a power source. 1-4-electrodes (anodes) respectively installed in cross-sections Z2, Z4, Z3, Z1 (see Fig. 1); 5 - power source; 6-vacuum chamber (cathode); V, V1, V2 voltmeters, $A$-ammeter (milliammeter); $R$ - ballast resistors

The cleaning mode was as described in [19]. After that, experiments were started with GDC without a magnetic field or in a field $B_{0} \approx 0.01 \mathrm{~T}$.

The residual pressure in the vacuum chamber was $p_{\text {o.p. }}=2 \cdot 10^{-5} \mathrm{~Pa}$. Then, a working gas was continuously puffed into the vacuum volume to a pressure of $0.1 \ldots 14 \mathrm{~Pa}$. High-purity argon $(99.998 \%)$ was used as a working gas.

Since the geometry of the cathode was the walls of the U-2M toroidal vacuum chamber, in this case, a hollow cathode discharge can be realized. Hollow 
cathode discharges $[20,21]$ often represent an independent gas discharge with cold cathodes. In these discharges, ionization of molecules (atoms) of a neutral gas occurs due to primary electrons emitted from the surface of the cathodes when a voltage is applied to the interelectrode gap and secondary emission when particles interact with the surface of the cathodes. And also plasma electrons can take part in gas ionization. Electric breakdown and the ignition of a self-maintained discharge in low-pressure gases occurs as a result of the development of Townsend breakdown, which has the character of electron avalanche multiplication [22, 23]. One of the peculiarities of a discharge with a hollow cathode is the inhomogeneity of the electric field in the discharge gap. In this case, the theoretical consideration of this type of discharge becomes much more complicated and often it is necessary to carry out additional experimental studies and measurements. In this case, first of all, it was required to determine the voltage of the discharge ignition on the gas pressure, as well as the current-voltage characteristics of the discharge.

The first switching on of the GDC showed that at a discharge current of more than $50 \mathrm{~mA}$, the discharge burns unstably, fluctuations in the voltage $U$ and the current $I_{\mathrm{d}}$ of the discharge appeared. The higher the discharge current was, the higher amplitude the fluctuations of $U$ and $I_{\mathrm{d}}$. were observed. Similar fluctuations in GDC were observed earlier on Wendelstein 7-X [9]. In this case, the fluctuations in the voltage and discharge current were associated with the formation of micro arcs on the surface of the vacuum chamber (cathode), which were observed visually (see Fig. 4). The formation of micro arcs is associated with the presence of dust and dielectric films on the cathode surface. In this case, the value of the discharge current was chosen such that there were practically no micro arcs and voltage (current) fluctuations. The situation gradually improved, and it possible to increase $I_{\mathrm{d}}$ to $500 \mathrm{~mA}$ without arcing and fluctuations in $U$ and $I_{\mathrm{d}}$. After this, the discharge ignition voltage and its currentvoltage (I-V) characteristics were measured.

Fig. 5 shows the dependence of the breakdown voltage on the Ar pressure. The minimum discharge ignition voltage was $U_{\min } \approx 253 \mathrm{~V}$, the value of which corresponds to the Stoletov point [23], where the ionization probability by the electron impact is maximum, and the conditions for repeatability of the discharge are optimal. At small $p$ (the left branch of the Paschen curve [23]), a very strong field is required to achieve the proper charges multiplication; therefore, the breakdown voltage rises rapidly with decreasing pressure. Due to the limited effective cross-section of ionization, the ionization coefficient is also limited. In the region of high pressures (on the right branch of the Pashen curve), the breakdown voltage increases almost proportionally to the pressure. This is due to the fact that in the case of high pressures or long gaps, the electron has the ability to make many ionizing collisions before reaching the anode.

In Fig. 6 shows a family of current-voltage characteristics (CVC) for three values of the working gas pressure. Dependencies have a slight positive slope.
The discharge currents increase with the increasing voltage across the electrodes. In the case of $p=0.6 \mathrm{~Pa}$, the discharge voltage across the two pairs of electrodes is practically the same. A slight difference in voltage of the order of $0.6 \ldots 0.7 \%$ is due to the measurement error.

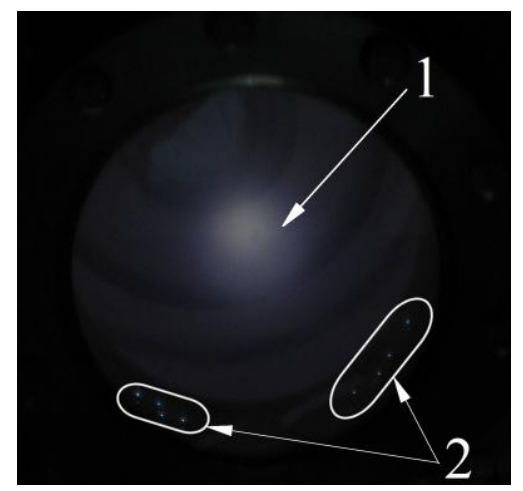

Fig. 4. Discharge photograph

1 -discharge glow in the flange, 2 - micro arcs

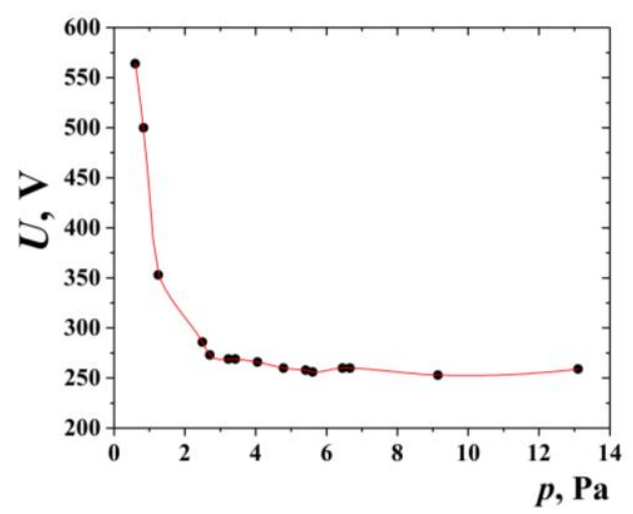

Fig. 5. Breakdown voltage versus Ar pressure

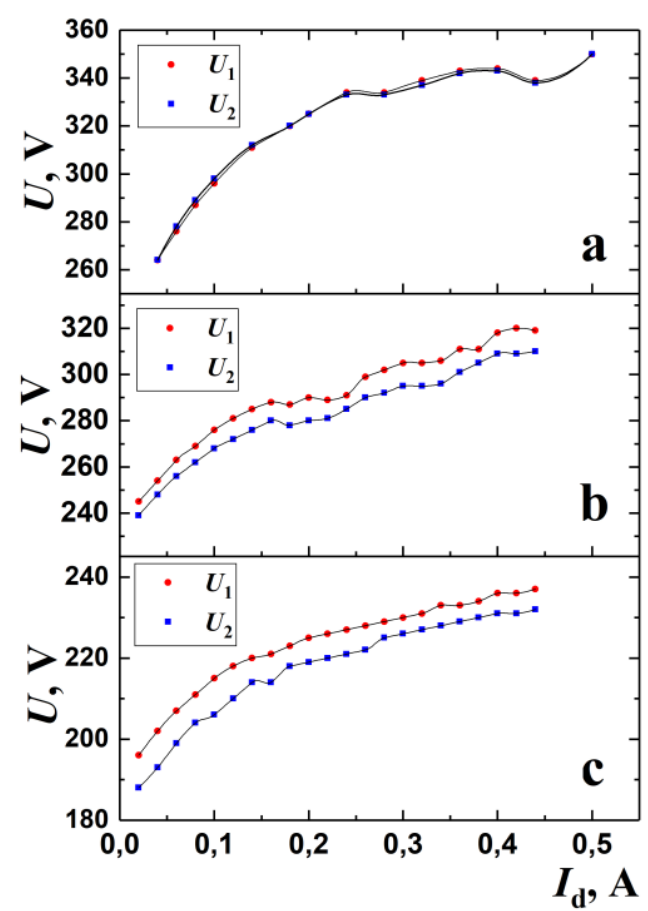

Fig. 6. CVC characteristics of the discharge at a pressure of $0.6 \mathrm{~Pa}(\mathrm{a}), 1.3 \mathrm{~Pa}(\mathrm{~b}), 6.7 \mathrm{~Pa}(\mathrm{c})$.

$\left(U_{1}\right.$ voltage on anodes 1 and $2, U_{1}$ voltage on anodes 3 and 4, see Fig. 3) 
The maximum power in the discharge was $175 \mathrm{~W}$ at a pressure of $0.6 \mathrm{~Pa}$. The glow of the gas discharge is observed throughout the optical window. In Fig. 7 shows photographs of the discharge in different sections of the chamber. In the case of pressure $p=6.7 \mathrm{~Pa}$, the difference in voltage across two pairs of electrodes is about $2.1 \ldots 4.1 \%$. In this case, the power delivered to the discharge was $\approx 100 \mathrm{~W}$.

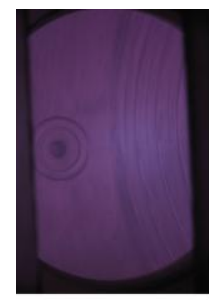

$a$

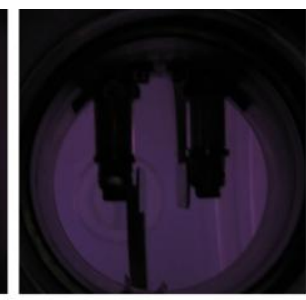

$b$

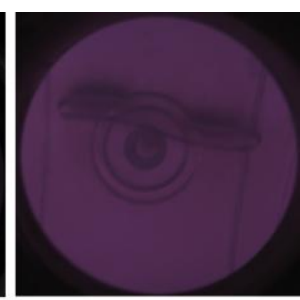

C
Fig. 7. A photograph of the discharge in different sections of the chamber $P 1(a), V(b)$, and $N(c)$ $(p=0.6 \mathrm{~Pa})$

It was of interest to conduct experiments with only one anode turned on. First, it is important for understanding the physics of the discharge. Multiple anodes complicate somewhat the consideration of the discharge. Secondly, from the technical point of view, it is important to realize the discharge if it is impossible to turn on all the anodes for technical reasons. Note that in large toroidal chambers, the presence of only one anode can lead to inhomogeneity of the plasma density and the density of the ion current per cathode (wall of the vacuum chamber) along the torus [24].

The experiments were carried out with only one anode turned on, installed in the $\mathrm{Z} 1$ section. In this case, the resistance of the ballast resistor was $1026 \Omega$. In the case of one anode, the value of the breakdown voltage corresponded to the previously measured value for the case of four anodes (see Fig. 5). The behavior of the I-V characteristic of a discharge with one anode was the same as for four anodes (Fig. 8). The discharge voltage and discharge current were close in value to those measured for 4 anodes. Thus, the maximum adsorbed power in the discharge was $87 \mathrm{~W}$ at a pressure of $0.8 \mathrm{~Pa}$. The dependence of the voltage across the discharge on the pressure at $I_{\mathrm{d}}=$ const is not monotonic (Fig. 9). In general, in this case, for a GDC, the behavior of the CVC and the dependence $U(p)$ at $I_{\mathrm{d}}=$ const are typical for a discharge with a hollow cathode [20, 21, 25]. Thus, under these experimental conditions, a discharge similar to a discharge with a hollow cathode was realized.

A discharge with a hollow cathode can also be realized in a magnetic field $[21,25]$. The I-V characteristics of discharges in a magnetic field and without a magnetic field were compared (Fig. 10). As seen from Fig. 10 at a discharge current of up to $0.04 \mathrm{~A}$, the discharge voltage in a magnetic field is slightly less than without it. At currents more than $0.05 \mathrm{~A}$, on the contrary, for example, at a current of $0.28 \mathrm{~A}$, the discharge voltage in a magnetic field is $40 \mathrm{~V}$ lower than without a magnetic field. Similar behavior of the I-V characteristic was observed earlier in [25].
In a stationary discharge, the total current $I_{\mathrm{a}}$ through the anode should be equal to the total current $I_{\mathrm{c}}$ through the cathode [22]. For GDC in large vacuum chambers, it is characteristic that the cathode area $S_{\mathrm{c}}$ is much larger than the area of the anodes $S_{\mathrm{a}}$ [26]. In this case, the $S_{\mathrm{c}} / S_{\mathrm{a}}$ ratio for the case of 4 anodes and one anode, respectively, is $\approx 7 \cdot 10^{-3}$ and $\approx 2 \cdot 10^{-3}$. Accordingly, the average value of the current density at the anodes will be higher than at the cathode.

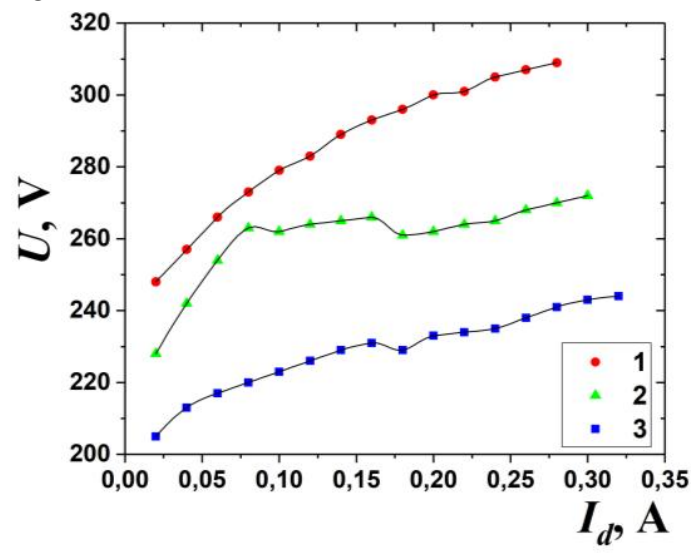

Fig. 8. CVC characteristics of the discharge at pressure: $1-0.8 \mathrm{~Pa}, 2-1.8 \mathrm{~Pa}, 3-5.6 \mathrm{~Pa}$

(one anode is included in the Z1 section)

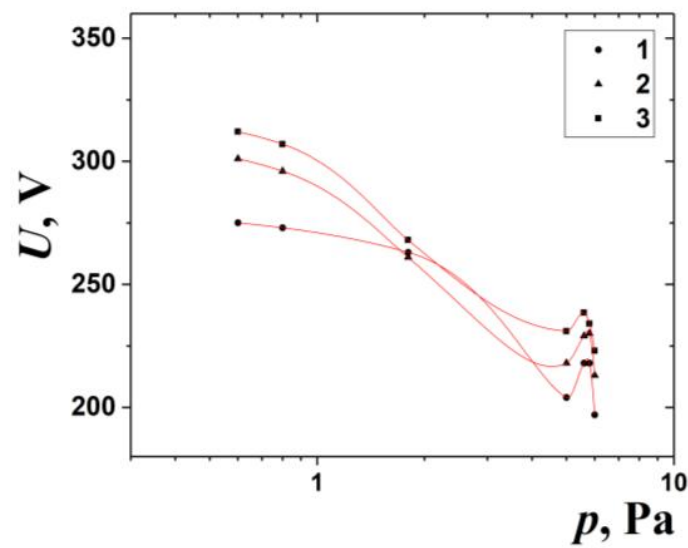

Fig. 9. Dependence of the discharge burning voltage on the pressure at the discharge current: $1-0.08 \mathrm{~A}$, $2-0.18$ A, 3-0.26 A (one anode is enabled in the Z1

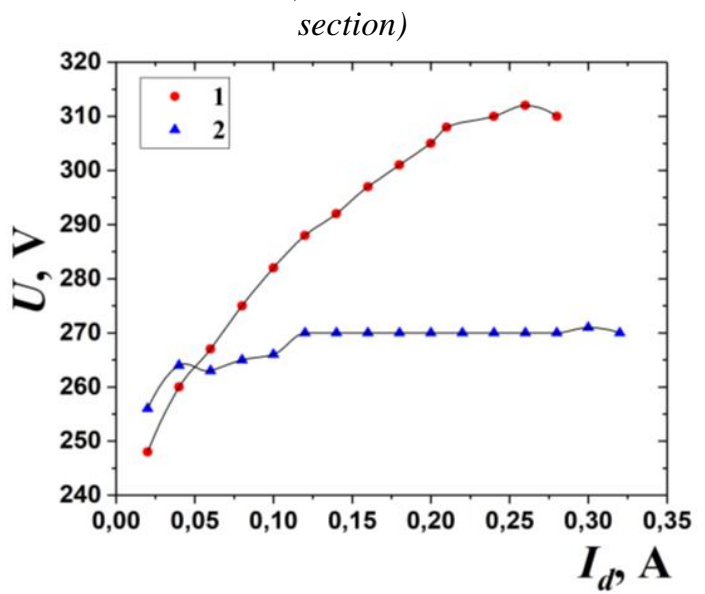

Fig. 10. CVC of the discharge at $B_{0}=0 T$ (1) and $B_{0} \approx 0.01 T(2)$ (one anode is included in the section Z1, $p=0.6 \mathrm{~Pa}$ ) 
An estimate shows that at a current of $0.5 \mathrm{~A}$, the average current density at the cathode is $j_{\mathrm{c}} \approx 2.2 \mu \mathrm{A} / \mathrm{cm}^{2}$, and at the anode, $j_{\mathrm{a}} \approx 321 \mu \mathrm{A} / \mathrm{cm}^{2}$. Note that the current density may not be substantially uniform over the surface of the electrodes, and the effective surface area is not equal to the geometric one. Depending on the geometrical factors of the anode and the discharge parameters, various sheath structures can be observed, such as: ion sheaths, electron sheaths, double sheaths, double layers, anode glow, fireballs, as well as anode spots [27].

Sputtering is one of the main processes leading to the destruction of the cathode material and, accordingly, its entry into the plasma. The main characteristic of the sputtering process is the sputtering coefficient $Y$, which depends on the charge and mass of the incident ion, its energy, angle of incidence, as well as on the material and temperature of the target. The sputtering coefficient $Y$ of iron by $\mathrm{Ar}^{+}$ions in the energy range $190 \ldots 350 \mathrm{eV}$ at normal incidence is in the range 0.37...0.67 [28]. For carbon $Y$ at the same energies of $\mathrm{Ar}^{+}$ions is in the range of $0.05 \ldots 0.15$ [28]. In the case of sputtering of a-C:H films by $\mathrm{Ar}^{+}$ions in the presence of neutral hydrogen atoms in the plasma, $Y$ significantly increases due to the mechanism of chemical sputtering [29]. Hydrogen can enter the discharge through the processes of dissociation of water and hydrogen-containing compounds.

\section{CONCLUSIONS}

The GDC system was developed, manufactured and installed on the U-2M. The design and technical features of this system are described. The first experimental studies of GDC in an argon atmosphere have been carried out. The dependence of the breakdown voltage on the argon pressure is determined. The CVC of the gas discharge were measured depending on the pressure of the working gas in the absence and presence of a magnetic field.

The GDC system at the U-2M expands the experimental possibilities when carrying out experiments on cleaning the vacuum chamber.

\section{ACKNOWLEDGEMENTS}

The work was done according to the program "Priority scientific research development support" in the project № 25/22-2019.

\section{REFERENCES}

1. J. Winter. Wall conditioning in fusion devices and its influence on plasma performance // Plasma Physics and Controlled Fusion. 1996, v. 38, № 9, p. 1503-1542.

2. T. Wauters, D. Borodin, R. Brakel, et al. Wall conditioning in fusion devices with superconducting coils // Plasma Physics and Controlled Fusion. 2020, v. 62, № 3, p. 034002.

3. E. De La Cal, E. Gauthier. Review of radio frequency conditioning discharges with magnetic fields in superconducting fusion reactors // Plasma Physics and Controlled Fusion. 2005, v. 47, №2, p. 197-218. 4. N.I. Nazarov, V.V. Plyusnin, T.Yu. Ranyuk. Cleaning of surfaces by plasma in the Uragan-3 torsatron // Fizika Plazmy. 1987, v. 13, № 12, p. 15111515 (in Russian).
5. A.V. Lozin, V.E Moiseenko, L.I. Grigor'eva, et al. Cleaning of inner vacuum surfaces in the Uragan-3M facility by radio-frequency discharges // Plasma Physics Reports. 2013, v. 39, № 8, p. 624-631.

6. V.E. Moiseenko, A.V. Lozin, V.V. Chechkin, et al. VHF discharges for wall conditioning at the Uragan-2M torsatron // Nuclear Fusion. 2014, v. 54, № 3, p. 033009.

7. A.V. Lozin, M.M. Kozulia, V.B. Korovin, et al. Wall conditioning discharges driven by T-shaped antenna in Uragan-2M // Problems of Atomic Science and Technology. Series «Plasma Physics». 2018, № 6, p. 50-53.

8. H. Amemiya, S. Ishii, H. Oyama et al. Study of metal deposition on low $\mathrm{Z}$ samples during ECR and glow discharge cleaning in TEXTOR // Journal of Nuclear Materials. 1987, v. 145, p. 647-650.

9. A. Goriaev, T. Wauters, R. Brakel, et al. Development of glow discharge and electron cyclotron resonance heating conditioning on W7-X // Nuclear Materials and Energy. 2019, v. 18, p. 227-232.

10. T. Wauters, R. Brakel, S. Brezinsek, et al. Wall conditioning by ECRH discharges and He-GDC in the limiter phase of Wendelstein 7-X // Nuclear Fusion. 2018, v. 58, № 6, p. 066013.

11. A Goriaev, T. Wauters, R. Brakel, et al. Wall conditioning at the Wendelstein 7-X stellarator operating with a graphite divertor // Physica Scripta. 2020, v. T171, p. 014063.

12. T. Härtl, A. Drenik, M. Kircher, et al. Optimization of the ASDEX Upgrade glow discharge // Fusion Engineering and Design. 2017, v. 124, p. 283-286.

13. D. Douai, S. Brezinsek, H. Esser, et al. Wall conditioning of JET with the ITER-like wall // Journal of Nuclear Materials. 2013, v. 438, p. S1172-S1176.

14. K. Nishimura, N. Ashikawa, S.Masuzaki, et al. Development of the plasma operational regime in the large helical device by the various wall conditioning methods // Journal of Nuclear Materials. 2005, v. 337, p. 431-435.

15. Z. Zhou, Y. Song, J. Hul. Design and application of GDC on EAST Tokamak // Fusion Engineering and Design. 2011, v. 86, p. 1599-1602.

16. Z. Khan, S. George, P. Semwal, et al. Conditioning of SST-1 tokamak vacuum vessel by baking and glow discharge cleaning // Fusion Engineering and Design. 2016, v. 103, p. 69-73.

17. Y. Yang, S. Maruyama, G. Kiss, et al. Re-design of ITER glow discharge cleaning system based on a fixed electrode concept // Fusion Engineering and Design. 2014, v. 89, p. 1944-1948.

18. V.E. Moiseenko, Y.V. Kovtun, T. Wauters, et al. First experiments on ICRF discharge generation by a W7-X-like antenna in the Uragan-2M stellarator // Journal of Plasma Physics. 2020, v. 86, p. 905860517.

19. Yu.V. Kovtun, V.E. Moiseenko, A.V. Lozin, et al. Characteristics of VHF Discharge $\mathrm{N}_{2}$ Plasma in Uragan2M Stellarator // Acta Physica Polonica A. 2020, v. 138, № 4, p. 632-637.

20. B.I. Moskalev. Hollow Cathode Discharges. M.: Energia, 1969, p. 184 (in Russian). 
21. V.I. Kolobov, A.S. Metel. Glow discharges with electrostatic confinement of fast electrons // Journal of Physics D: Applied Physics. 2015, v. 48, № 23, p. 1-10.

22. M.A. Liberman, A.J. Lichtenberg. Principles of plasma discharges and materials processing. "John Wiley and Sons", 2005, p. 757.

23. Y.P. Raiser. Gas Discharge Physics. Springer: Verlag Berlin, 1991, p. 449.

24. D. Kogut, D. Douai, G Hagelaar, et al. Modelling of ITER Glow Discharge Cleaning II: Comparison with Experiments and Application to ITER // Plasma Phys. Control. Fusion. 2015, v. 57, p. 233001.

25. A.N. Ozerov, Yu.V. Kovtun, E.I. Skibenko, et al. Investigation of gas discharge burn conditions in a Penning geometry in gradient magnetic fields // Problems of Atomic Science and Technology. Series «Plasma Physics». 2017, № 1, p. 211-214.
26. G.J.M. Hagelaar, D. Kogut, D. Douai, et al. Modelling of tokamak glow discharge cleaning I: physical principles // Plasma Physics and Controlled Fusion. 2015, v. 57, № 2, p. 025008.

27. Scott D Baalrud, B. Scheiner, T. Yee Benjamin, et al. Interaction of biased electrodes and plasmas: sheaths, double layers, and fireballs // Plasma Sources Science and Technology. 2020, v. 29, № 5, p. 053001.

28. Y. Yamamura, H. Tawara. Energy dependence of ion-induced sputtering yields from monatomic solids at normal incidence // Atomic data and nuclear data table. 1996, v. 62, № 2, p. 149-253.

29. M. Schlüter, C. Hopf, W. Jacob. Chemical sputtering of carbon by combined exposure to nitrogen ions and atomic hydrogen // New Journal of Physics. 2008, v. 5, № 1, p. 053037.

Article received 23.12 .2020

\section{КОНСТРУКЦИЯ И ПРИМЕНЕНИЕ ТЛЕЮЩЕГО РАЗРЯДА ДЛЯ ЧИСТКИ В СТЕЛЛАРАТОРЕ УРАГАН-2М}

Ю.В. Ковтун, В.Е. Моисеенко, С.М. Мазниченко, А.В. Лозин, В.Б. Коровин, Е.Д. Крамской, Е.В. Сюсько, М.М. Козуля, А.Ю. Красюк, В.М. Листопад, Д.И. Барон

На стеллараторе Ураган-2М разработана система для чистки стенок вакуумной камеры тлеющим разрядом. Представлен обзор системы тлеющего разряда. Проведены первые экспериментальные исследования разряда в атмосфере аргона. Определена зависимость пробивного напряжения от давления аргона. Измерены вольт-амперные характеристики газового разряда в зависимости от давления рабочего газа при отсутствии и наличии магнитного поля.

\section{КОНСТРУКЦІЯ І ЗАСТОСУВАННЯ ЖЕВРІЮЧОГО РОЗРЯДУ ДЛЯ ЧИСТКИ В СТЕЛАРАТОРІ УРАГАН-2М}

\section{Ю.В. Ковтун, В.С. Моісеєнко, С.М. Мазніченко, О.В. Лозін, В.Б. Коровін, С.Д. Крамський, С.В. Сюсько, М.М. Козуля, О.Ю. Красюк, В.М. Листопад, Д.І. Барон}

На стелараторі Ураган-2М розроблена система для чищення стінок вакуумної камери жевріючим розрядом. Представлено огляд системи жевріючого розряду. Проведено перші експериментальні дослідження розряду в атмосфері аргону. Визначено залежність пробивної напруги від тиску аргону. Виміряні вольт-амперні характеристики газового розряду в залежності від тиску робочого газу при відсутності і наявності магнітного поля. 